\title{
The Utility of GIS for Assessing the Ecological State and Managing Armenian's Farmlands
}

\author{
Armen Saghatelyan, Shushanik Asmaryan, Vahagn Muradyan and Garegin Tepanosyan \\ Center for Ecological-Noosphere Studies NAS RA, Abovyan 68, Yerevan 0025, Armenia
}

\begin{abstract}
The practicable solution to the problem of degradation of mountainous pastures/hayfields provoked by unplanned and unregulated use of farmlands is considered in the article. With the view of developing animal husbandry and managing pastures/hayfields, in 2011-2012, the Government of the Republic of Armenia under support of the World Bank implemented a Farm Resources Management and Competitiveness Program. The goal of the Program is ceasing a trend to overgrazing and degradation of close-to-village sites, using remote pastures/hayfields in the best effective manner, improving feed production and animal feeding networks, and promoting a growth in animal feed production volumes. To achieve that, the following works were planned and implemented successfully in 23 rural communities of six marzes of the RA (Republic of Armenia), which was done by three stages. For the 23 communities series of cartographic layers was produced and a relevant database was compiled and mapped.
\end{abstract}

Key words: GIS, ecological state, farmlands, pasture, Armenia.

\section{Introduction}

The territory of the RA (Republic of Armenia) occupies an area of $29.8 \mathrm{~km}^{2}$, the major part of which falls on farmlands located at a height of 400-3,200 m above sea level [1, 2]. Such a variation in altitude complicates development of territories especially in the case they have an extensive character stemmed from the Soviet era: land plowing on sites lying at a very steep angle of decline $>20$ grade, unregulated grazing, and so on. A long-term, unplanned and unregulated use of farmlands entailed intense washout of upper soil horizon, which subsequently provoked intense development of erosion and degradation of lands [3, 4]. A practicable solution to this problem is a scientifically and methodically grounded assessment of ecological state of farmlands and economically competent planning and management of agricultural resources.

With the view of developing animal husbandry and managing pastures/hayfields, in 2011-2012, the Government of the Republic of Armenia under support

Corresponding author: Shushanik Asmaryan, Ph.D., research fields: GIS, spatial data infrastructures, remote sensing, geomorphology, and landscape planning. E-mail: ashuk@ecocentre.am. of the World Bank implemented a Farm Resources Management and Competitiveness Program. The goal of the Program is ceasing a trend to overgrazing and degradation of close-to-village sites, using remote pastures/hayfields in the best effective manner, improving feed production and animal feeding networks, and promoting a growth in animal feed production volumes.

\section{Method and Materials}

Implementation of tasks and ongoing studies planned in the frame of this program, are supported by a series of published scientific and methodical sources devoted to physical and geographical conditions and landscape belts of Armenia's territories [5]: The pasture sites were selected and mapped employing morphological and morphometric methods $[4,6]$, whereas assessment of ecological status (total stoniness and degradation level) was done through field measurements and analysis and interpretation of satellite images in cameral conditions [7, 8].

The following works were planned and implemented successfully in 23 rural communities of six marzes of the RA, which was done by three stages. In preparatory 
stage through collation between maps and satellite images visual signatures of separate objects (cliffs, rocky river slopes, etc.) were developed, which in chamber conditions would help calculate and exclude idle, vegetation-barren and impassable areas from pastures. Based on field observations and tests, the overall state of natural pastures and the level of degradation were assessed. In final stage for the 23 communities series of cartographic layers were produced that included relief, river-ravine and road networks, infrastructure, data on land use and soil types in the noted communities were processed, and a relevant database was compiled and mapped. Finally, with a view of assessing the usable area of vegetation cover on the grazing sites, the area occupied by objects found on separate pastures (stone contents, stone fields, rocks, rocky-side ravines, etc.) was calculated. The latter underpinned the assessment of ecological status of all the grazing sites.

Prior to mapping the communities and implementation of grassland productivity studies and assessment works there, a series of meeting had been held with the PUU (Pasture Users Union) community assistant teams, community leaders, representatives and experts of PUU (Fig. 1). The meetings included discussions concentrated on numerous organizational pasture management and livestock farming issues. In particular, from local self-governance bodies

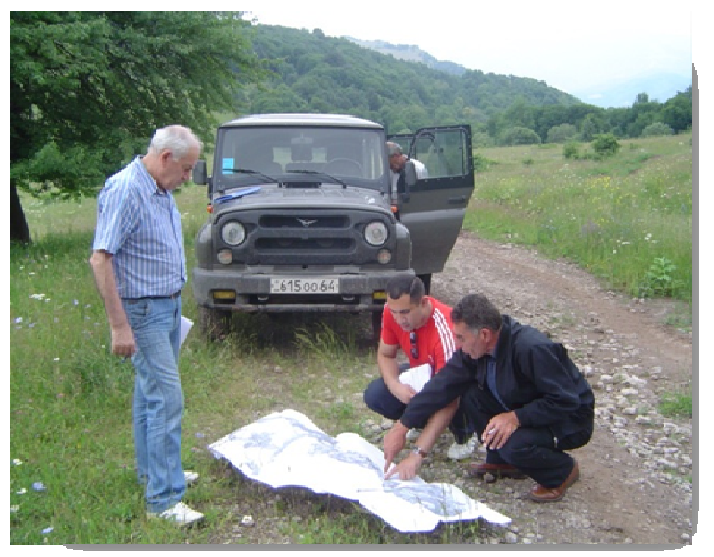

information was collected regarding major directions of farm activities, farmland types, a total population of large and small horned cattle, composition of herds and flocks, feed demand, volumes of produced, stocked and purchased feed, duration of grazing and stall feeding periods. Cadaster data were collated with available maps, local names of pastures, dimensions and limits of pasture sites and usable and unusable plots within their bounds. Modern infrastructures (gas pipes, irrigation points and high voltage electric wire) were specified and schematic maps were produced.

The research was implemented employing traditional and up-to-date methods with an emphasis on the latest GIS and remote sensing methods. Data support consisted of topographic maps scale $1: 10000$, thematic maps (landscape, geomorphologic, etc.), satellite images (SPOT, QuickBird, Terra Modis, GeoEye, etc.), scientific archival literature and reports. The databases were created and developed in the environment AutoCAD 2010 and ArcGIS 9.2.

\section{Discussions}

In the result series of cartographic layers were produced and a relevant database was compiled and mapped for the 23 communities of six administrative districts (marzes). The discussion of the results obtained will be considered by Harzhisrural community.

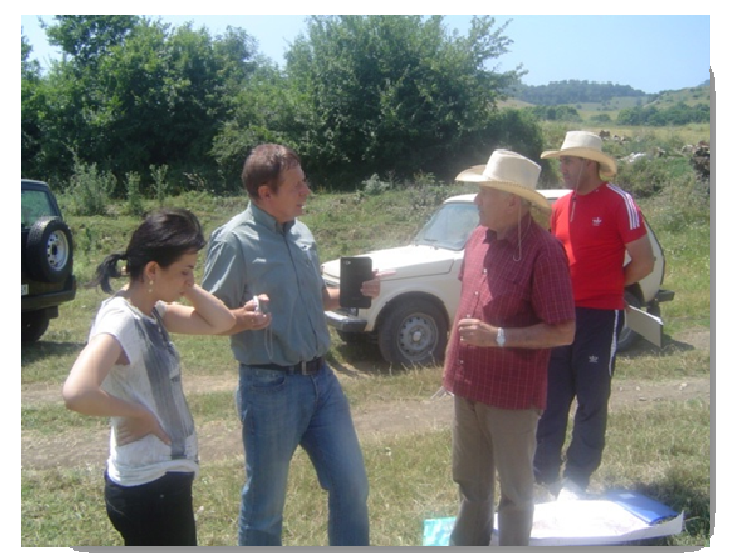

Fig. 1 Meetings and discussions with experts and representatives of local self-governance bodies. 


\section{Community of Harzhis}

Community of Harzhis has a population of 831 people and 175 home farms. The community lies on the Syuniki volcanic plateau within the bounds of mountain-meadow-steppe, sub-alpine meadow and alpine mountain-meadow landscape belts. It possesses 5,629 ha of different-purpose land, 2,218 ha out of which being pasture sites and 775 ha-arable land (Table 1). Based on the area of the community pasture sites and the number of large and small horned cattle (738 cattle head), one may conclude that the share of one cattle head - an area of 3.0 ha-meets a standard set by the RA Government resolution $\mathrm{N}^{0} 389$ as of 2011 [4].

\section{Physical and Geographical Specificities of the Community}

Harzhis community lies in the following consecutive main and intermediate landscape belts (Figs. 2 and 3).

\subsection{Mountain-Meadow-Steppe Belt}

The belt is intermediate between mountain-steppe and alpine mountain-meadow belts. The quantity of biomass there gradually reduces with a temperature decrease and as a lower section of a successive alpine belt it exhibits a spread of sub-alpine grasses. Climatic conditions are characterized by humid winter, low temperature in summer and even distribution of atmospheric precipitation during vegetation period. Atmospheric precipitation varies from 650 to $700 \mathrm{~mm}$, and in summer months hail events are more frequent. A frosty period lasts from September to May. A frost-free period lasts 4-4.5 months. Soils are exclusively diverse and are dominated by varities of mountain-meadow black soils.

\subsection{Sub-alpine Meadow Belt}

The bounds of this belt are strongly conditional. In contrast to the above described mountain-meadow-steppe belt, summer months in sub-alpine meadow belt are cooler and a frosty period starts in August. Atmospheric precipitation does not exceed $700 \mathrm{~mm}$. The soils are of typical mountain-meadow swamp-soddy types, their thickness often overstepping 50-60 cm. On some patches soils differ by stone contents. Specific composition of meadow plants is very diverse and includes some 120-130 species.

\subsection{Alpine Mountain-Meadow Belt}

Natural processes there run in conditions of low temperatures and relatively high humidity. Winter period is long (5-6 months) and snowy. Mean air temperature in winter is $-10{ }^{\circ} \mathrm{C}$, the lowest $-46{ }^{\circ} \mathrm{C}$. Vegetation period lasts 2-3 months. A soil formation process runs in conditions of a persistent snow cover. Low temperatures contribute to origination of a thick humic layer. The belt is characterized by mountain-meadow cinnamonic soddy soils. The most widespread plant species include dandelion, blue-bells, alpine meadow grass, sedge, wormwood, feather grass, and clover. A specific feature of the landscapes of those belts is that separate cliffs, boulders and vast stone-fields often violate homogenous vegetation cover there. Those formations have unique vegetation cover, whose composition largely depends on slope

Table 1 Land ownership structure in Harzhis community.

\begin{tabular}{lllll}
\hline \multirow{2}{*}{ Farmland types } & \multirow{2}{*}{ Area/ha } & \multicolumn{3}{c}{ Allocation according to type of ownership, ha } \\
\cline { 4 - 5 } & & Private & Community & State \\
\hline Arable land & 1,157 & 897 & 51 & 209 \\
Pasture sites & Close-to-village & 667 & & 540 \\
Close-to-home plots of land & 1,551 & 44 & - & - \\
Land for other purposes* & 44 & - & 2,210 & - \\
Total & 2,210 & 941 & 2,801 & 1,887 \\
\hline
\end{tabular}




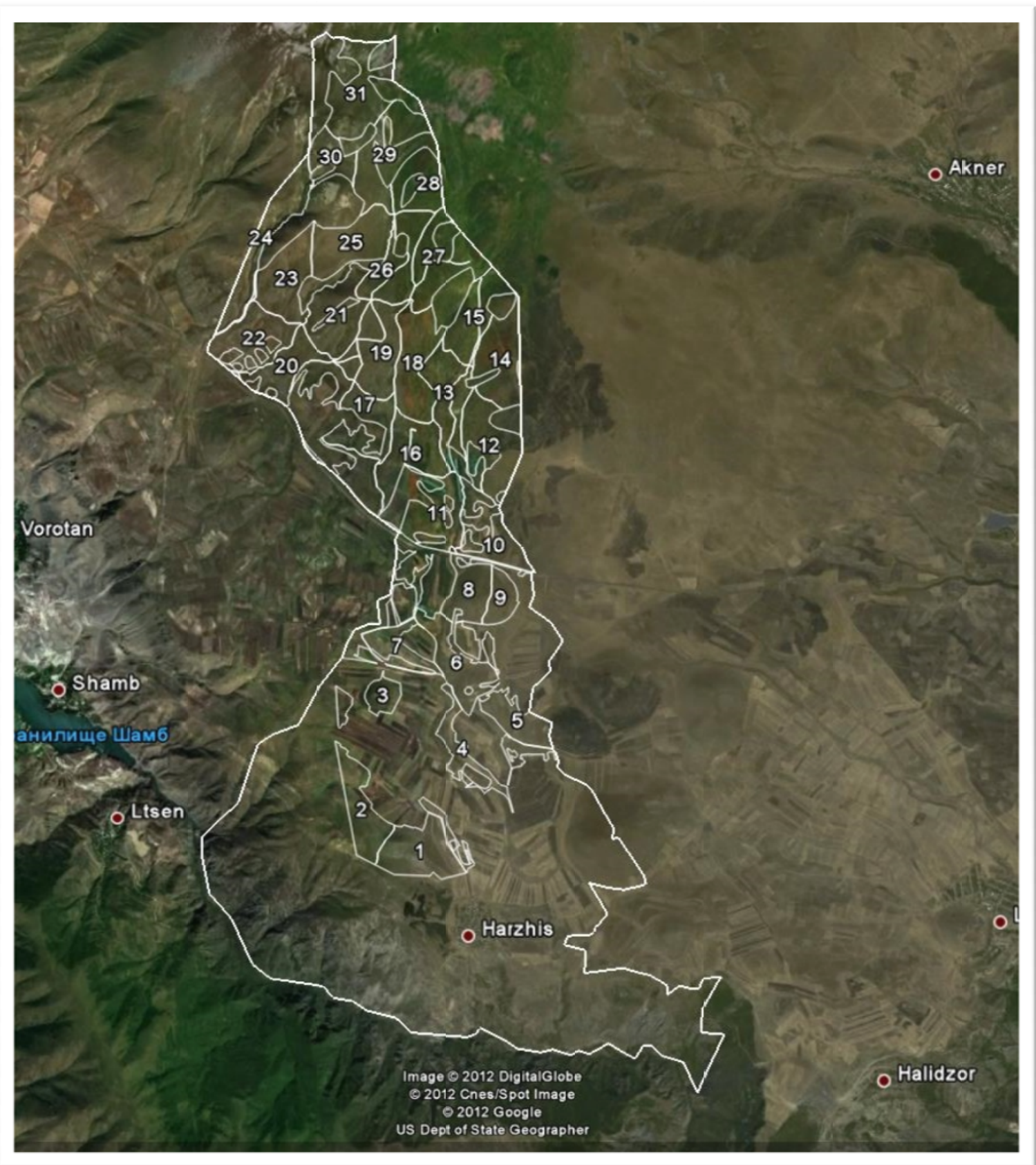

Fig. 2 A schematic map of pasture sites positioning in community of Harzhis.

aspects and micro-conditions of stony accumulations (presence of fine soils, humidity accumulation conditions, dimensions of cliffs and boulders, etc.).

Like mountain-meadow-steppe belt, in alpine belt either no arable farming is developed because of a lack of appropriate temperatures required for cultivated plants. Hence, the noted belts are treated in the republic as summer animal camps.

\subsection{Ecological Characteristic of Pasture Sites}

Within the bounds of the noted belts, 31 pasture sites were isolated (Table 2).

Within mountain-meadow-steppe belt, we isolated close-to-village pastures sites of Khootis 1, 2, Dahnai dzor, Ghashgha tapa, Avazahank, Karvasarai taratsk, Gyoli taratsk, Karablour 1, 2, Chobantapa 1, 2. A degree 


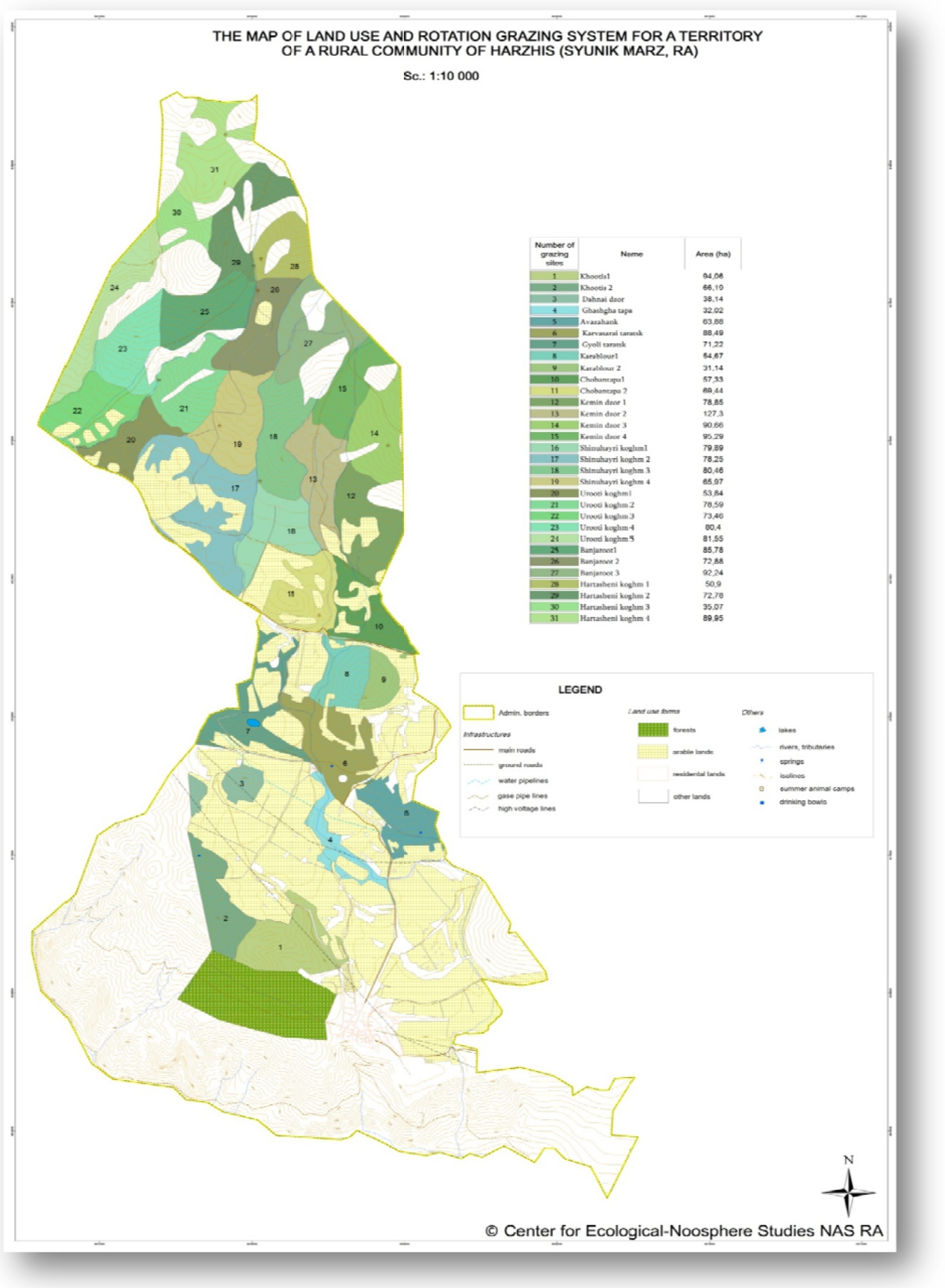

Fig. 3 A rotation grazing network for a rural community of Harzhis. 
Table 2 Elements and other areas found on pasture sites (\%).

\begin{tabular}{|c|c|c|c|c|c|c|c|c|c|}
\hline No. & Name of grazing sites & $\begin{array}{l}\text { Stone } \\
\text { contents }\end{array}$ & $\begin{array}{l}\text { Cliffy ravines, } \\
\text { rivers }\end{array}$ & Earth road & $\begin{array}{l}\text { Buildings, } \\
\text { structures }\end{array}$ & $\begin{array}{l}\text { Lakes, } \\
\text { ponds }\end{array}$ & $\begin{array}{l}\text { Trees, } \\
\text { bushes }\end{array}$ & $\begin{array}{l}\text { Area covered with } \\
\text { vegetation }\end{array}$ & $\begin{array}{l}\text { Total area of a } \\
\text { pasture site, ha }\end{array}$ \\
\hline 1 & Khootis 1 & 12.00 & & & & & & 88.00 & 94.06 \\
\hline 2 & Khootis 2 & 7.00 & & & & & & 93.00 & 66.19 \\
\hline 3 & Ghashgha tapa & 9.00 & & 0.47 & & & 7.00 & 83.53 & 32.02 \\
\hline 4 & Dahnaidzor & 15.00 & 0.94 & & & & & 84.06 & 38.14 \\
\hline 5 & Avazahank & 12.00 & & & & & & 88.00 & 63.88 \\
\hline 6 & Karvasaraitaratsk & 17.00 & 0.23 & & & & & 82.77 & 88.49 \\
\hline 7 & Gyolitaratsk & 10.00 & 0.28 & & & 1.00 & & 88.72 & 71.22 \\
\hline 8 & Karablour 1 & 18.00 & & & & & & 82.00 & 54.67 \\
\hline 9 & Karablour 2 & 13.00 & & & & & & 87.00 & 31.14 \\
\hline 10 & Chobantapa 1 & 16.00 & & & & & & 84.00 & 57.33 \\
\hline 11 & Chobantapa 2 & 18.00 & 0.29 & & & & & 81.71 & 69.44 \\
\hline 12 & Shinuhayrikoghm 1 & 15.00 & & & & & & 85.00 & 79.89 \\
\hline 13 & Shinuhayrikoghm 2 & 20.00 & 0.51 & & 0.26 & & & 79.23 & 78.25 \\
\hline 14 & Shinuhayrikoghm 3 & 16.00 & 0.50 & & & & & 83.50 & 80.46 \\
\hline 15 & Shinuhayrikoghm 4 & 19.00 & & & & & & 81.00 & 65.97 \\
\hline 16 & Kemindzor 1 & 17.00 & & 0.38 & & & & 82.62 & 78.85 \\
\hline 17 & Kemindzor 2 & 19.00 & & & & & & 81.00 & 127.30 \\
\hline 18 & Kemindzor 3 & 24.00 & 0.44 & & & & & 75.56 & 90.66 \\
\hline 19 & Kemindzor 4 & 25.00 & 0.21 & 0.31 & & & & 74.48 & 95.29 \\
\hline 20 & Urootikoghm 1 & 16.00 & 0.74 & 0.48 & & & & 82.77 & 53.84 \\
\hline 21 & Urootikoghm 2 & 16.00 & 0.13 & & & & & 83.87 & 78.59 \\
\hline 22 & Urootikoghm 3 & 18.00 & 0.54 & 0.41 & & & & 81.05 & 73.46 \\
\hline 23 & Urootikoghm 4 & 19.00 & 0.25 & & & & & 80.75 & 80.40 \\
\hline 24 & Urootikoghm 5 & 24.00 & & & & & & 76.00 & 81.55 \\
\hline 25 & Banjaroot 1 & 16.00 & 0.23 & 0.70 & & & & 83.07 & 85.78 \\
\hline 26 & Banjaroot 2 & 16.00 & 0.27 & & & & & 83.73 & 72.88 \\
\hline 27 & Banjaroot 3 & 15.00 & 0.43 & & 0.11 & & & 84.46 & 92.24 \\
\hline 28 & Hartashenikoghm 1 & 20.00 & & & 0.39 & & & 79.61 & 50.90 \\
\hline 29 & Hartashenikoghm 2 & 17.00 & & 0.54 & 0.07 & 0.30 & & 82.10 & 72.78 \\
\hline 30 & Hartashenikoghm 3 & 19.00 & & 1.71 & & & & 79.29 & 35.07 \\
\hline 31 & Hartashenikoghm 4 & 24.00 & & & & & & 76.00 & 89.95 \\
\hline
\end{tabular}

of stoniness of the noted pasture sites is above average 15\%-18\%, a large share falling also onstone slides, except pasture sites of Khootis 2 and Ghashgha tapa, where it makes $7 \%-9 \%$. Ecological status of the close-to-village pastures is poor, and there one may observe sharply inclined slopes with soils degraded in the result of overgrazing and permanent movement of animals; in this respect one should emphasize Dahnai dzor. The status of Khootis 1, 2 pasture sites is relatively good. One more cause of pasture degradation is a presence of a sandpit. The ecological status of the pastures is under a substantial impact of roads and operating farm machines.
Within sub-alpine meadow belt, we isolated pasture sites of Kemin dzor 1, 2, Shinuhayri koghm 1, 2, 3, 4 and Urooti koghm 1, 2, 3, 4, 5. A degree of stoniness is high, and the sites comprise vast stone-fields. On inclined slopes, one may identify soil erosion risks. In contrast to close-to-village pastures, ecological status of the noted pastures is relatively good.

Within alpine mountain-meadow belt, Kemindzor 3, 4, Banjaroot 1, 2, 3 and Hartasheni koghm 1, 2, 3, 4 pasture sites were isolated. A degree of stoniness of pastures located within the noted belt reaches $25 \%$, and a large share falls on steep slopes that are a prerequisite for triggering a soil erosion process. Ecological status 
of the remote pastures is good, and soil degradation risks are low due to under-grazing.

\section{Conclusion}

- In pastures sites the observed erosion risks are associated with steep deep canyons and steep slopes;

- The main reasons for the degradation of pastures are continuous movement of livestock overgrazing and the presence of the road network;

- The created databases of pastures will provide an opportunity to effectively manage heavily grazed pastures of the community, increase their productivity and improve the ecological status.

\section{Acknowledgments}

This material is based on the work implemented in frame of Carmac project lead by the "Agricultural project implementation unit" State agency of the Ministry of Agriculture RA under support of the World Bank.

\section{References}

[1] AS ArmSSR, ed. 1971. Physical Geography of the
Armenian SSR. Yerevan: AS ArmSSR.

[2] Isachenko, A. G. 1991. Landscape Science and Physico-Geographical Zonation. Moscow: High school.

[3] Habich, E. F. 2001. Ecological Site Inventory (Technical Reference 1734-7). Denver, Colorado: BLM, NBC.

[4] RA Government. 2011. Regulation of Pasture and Grassland Use. Yerevan: RA Government Resolution.

[5] Mezhunts B., Navasardyan M., and Sargsyan T. 2010. "The State of the Arid Steppe Belt Pastures of Ararat Valley of Armenia and the Ways of Its Optimization.” In Proceedings of the International Conference "Sustainable Development of Mountainous Territoriesunder the Global Change”, 119-23.

[6] Hill, M. J., Donald, G. E., Donnelly, J. R., and Moore, A. D. 2000. "Integrating Spatial Data with a Grazing System Model: Assessing Variability of Pasture and Animal Production at a Regional Scale.” Asian-Aus. J. Anim. Sci. 13 (Supplement July C): 128-31.

[7] Jianlong, L., Tiangang, L., and Quangong, C. 1998 "Estimating Grassland Yields Using Remote Sensing and GIS Technologies in China." New Zealand Journal of Agricultural Research 41: 31-8.

[8] Yan, W., Wunian, Y., and Mingsheng, L. 2003. Application of RS-GIS-GPS Technology in the Evaluation of Changing Cultivation into Forestry/Grassland. Presented at the Asia GIS 2003 Conference, Wuhan, China. 